\title{
PELATIHAN MICROSOFT PROJECT BAGI GURU-GURU SMK DI WILAYAH KERJA 4 PROVINSI JAWA TIMUR
}

\author{
Heri Suryaman $^{1 *}$, Hendra Wahyu Cahyaka ${ }^{1}$, Krisna Dwi Handayani ${ }^{1}$, \\ Mas Suryanto HS ${ }^{1}$
}

${ }^{1}$ Fakultas Teknik, Universitas Negeri Surabaya, Surabaya, Indonesia

*Email: herisuryaman@unesa.ac.id

\section{Informasi Artikel Abstrak}

Kata kunci:

Pelatihan Guru SMK, Pelatihan Microsoft Project

Diterima: $30-11-2021$ Disetujui: 10-01-2022 Dipubikasikan: 28-012022
Guru wajib dan mampu berkembang menghadapi perkembangan teknologi. Pola pengajaran yang mampu mengubah peserta didik dari tidak bisa menjadi bisa memang baik. SMK di wilayah kerja 4 Jawa Timur telah bersepakat memerlukan pelatihan secara rutin untuk meningkatkan skill baik dalam hal materi bidang studi. Tujuan kegiatan pelatihan Microsoft project ini yaitu : (1) Peningkatan kompetensi professional bagi guru; dan (2) Peningkatan kerja sama antara SMK dengan Universitas Negeri Surabaya. Metode pelaksanaan kegiatan pada pelatihan yaitu pembuatan kurva "S" yang lebih detail menggunakan program Microsoft Project bagi guru-guru di SMK di Wilayah Kerja 4 Provinsi Jawa Timur. Kegiatan pelatihan Microsoft Project, meliputi: (1) Ceramah / penjelasan, Tanya jawab secara daring; (2) Diskusi dengan menuangkan pokok pikiran berkaitan dengan pembelajaran materi dan praktek Rencana Anggaran Belanja (RAB); (3) Praktek mengoperasikan Microsoft Project dipandu oleh Tim PKM; dan (4) Evaluasi hasil kegiatan pelatihan. Kegiatan pelatihan Microsoft Project secara daring ini sebagai alternative solusi pelaksanaan PKM di masa pandemic Covid-19. Capaian keberhasilan setiap peserta pelatihan sebanyak 38 guru rata-rata sebesar $82 \%$. Terjadi peningkatan kompetensi professional bagi guru setelah mengikuti pelatihan. Selain itu juga, dengan terselenggaranya pelatihan ini dapat memberikan peningkatan kerja sama SMK se-wilayah kerja 4 Provinsi Jawa Timur dan Universitas Negeri Surabaya.
Keywords:

Vocational Teacher Training, Microsoft Project Training

\section{Abstract}

Teachers are required and able to develop in the face of technological developments. Teaching patterns that are able to change students from not being able to be good are indeed good. Vocational High Schools in the working area of East Java 4 have agreed to require regular training to improve skills both in terms of subject matter. The objectives of this Microsoft project training activity are: (1) Improving professional competence for teachers; and (2) Increasing cooperation between SMK and Surabaya State University. The method of implementing the activities in the 
training is making a more detailed "S" curve using the Microsoft Project program for teachers in SMK in Work Area 4, East Java Province. Microsoft Project training activities, including: (1) Lectures / explanations, question and answer boldly; (2) Discussion by expressing the main ideas related to the material learning and practice of the Expenditure Budget Plan (RAB); (3) The practice of operating Microsoft Project is guided by the PKM Team; and (4) Evaluation of the results of training activities. This bold Microsoft Project activity is an alternative solution for implementing PKM during the Covid-19 pandemic. The success of each training participant was 38 teachers, an average of $82 \%$. There was an increase in professional competence for teachers after attending the training. In addition, the implementation of this training can provide an increase in cooperation between Vocational High Schools in the 4 working areas of East Java Province and the State University of Surabaya.

\section{PENDAHULUAN}

Para guru harus memiliki kualitas dan kemampuan yang baik. Skill atau yang sering disamakan dengan keahlian wajib dimiliki oleh guru. Skill bisa didapat dari pengalaman guru sehari-hari, bahkan bertahun-tahun. Pengembangan dimulai dari diri sendiri, artinya guru harus mampu mengenal bagaimana cara mengembangkan kualitas secara pribadi. Pelatihan, seminar, workshop adalah contoh sederhana cara pengembangan kualitas guru. Guru pun wajib mau dan mampu berkembang menghadapi perkembangan teknologi. Pada pelatihan keterampilan pembuatan media menunjukkan menunjukkan bahwa peningkatan pengetahuan peserta signifikan dan masuk kategori tinggi (Hidayat et al., n.d.). Pola pengajaran yang mampu mengubah peserta didik dari tidak bisa menjadi bisa memang baik. Dalam PKM terdahulu peserta mampu mengimplementasikan nilai-nilai etika setalah mengikuti pelatihan (Wena et al., 2019). Guru program keahlian teknik bangunan harus mampu mendidik, mengajarkan materi dengan sebaik-baiknya. Sehingga, peserta didik harus mampu menyerap materi dan proaktif. Selanjutnya terkait dalam kegiatan pendampingan menunjukkan bahwa setelah mengikuti kegiatan pendampingan, peserta mampu menerapkan teori dan praktik (Arief et al., 2020).

SMK Negeri 2 Bojonegoro telah menjalin kerjasama sejak tanggal 22 Januari 2019 dengan lingkup Program Peningkatan Pendidikan dan Pembelajaran, Penelitian, Karya Ilmiah, Pengabdian kepada Masyarakat, kemahasiswaa/kesiswaan dan pertukaran Informasi. Kerjasama tersebut, telah disahkan ke dalam sebuah format MoU (Memorandum of Understanding) antara SMK Negeri Kudu Jombang bersama Fakultas Teknik Unesa.

Dari hasil survei yang telah dilakukan serta diskusi dengan teman-teman guru SMK Negeri/Swasta Kota/Kab Jombang dan Sekitarnya (Jombang, Nganjuk, Ngawi, Ponorogo) didapat informasi bahwa, guru-guru yang mengajar memerlukan materi-materi: AutoCAD 2D, AutoCAD 3D, $3 d s$ max, MS Project, Revit Building, Sketchup, SAP 2000, materi Konstruksi Bangunan dan 
materi terkini. Untuk menjawab permasalahan tersebut, guru-guru menginginkan pengayaan terkait materi - materi keahlian bidang studi. Berdasarkan kenyataan di lapangan dan usulan dari beberapa sekolah maka tim PKM UNESA mengusulkan untuk memberikan pelatihan materi Microsoft Project secara daring bagi guru-guru SMK di Wilayah Kerja 4 Provinsi Jawa Timur. Melalui pelatihan materi pengayaan diharapkan juga dapat menunjang tuntutan kompetensi yang harus dimiliki guru serta dapat meningkatkan kualitas pembelajaran guru dalam pelaksanaan pengajaran di sekolah dan peningkatan pembelajaran di kelas.

Musyawarah Guru Mata Pelajaran (MGMP) Program Keahlian Teknik Bangunan SMK Negeri/Swasta Kota/Kab Jombang dan sekitarnya juga telah mengirimkan Surat Permohonan Narasumber pada tanggal 4 Mei 2020, dalam rangka mengembangkan kompetensi tenaga pendidik dan pengajar untuk memberikan pengayaan pada materi perencanaan time schedule yang lebih detail menggunakan program MicroSoft Project. PKM terdahulu yang relevan terkait dengan pelatihan menunjukkan hasil bahwa peserta pelatihan mampu memahami penerapan pengelolaan dalam meningkatkan omset (Cahyono \& Suryawirawan, 2021). Selanjutnya pelatihan daring kedua menunjukkan bahwa kegiatan pelatihan secara daring dapat berhasil meningkatkan pengetahuan, pemahaman, dan minat usaha mitra sasaran (Sopandi, 2021).

Berdasarkan pada hasil analisis situasi, maka permasalahan mitra adalah bagaimanakah keterlaksanaan pelatihan MicroSoft Project dalam rangka peningkatan pembelajaran di kelas sebagai profesionalisme guru?

Tujuan kegiatan pengabdian kepada Masyarakat Jurusan Teknik Sipil Universitas Negeri Surabaya dengan mitra dari SMK se wilayah kerja 4 di Provinsi Jawa Timur adalah:

1. Peningkatan kompetensi professional bagi guru

2. Peningkatan kerja sama antara SMK dengan Universitas Negeri Surabaya.

Program Keahlian Teknik Bangunan pada SMK Untuk wilayah kerja 4 meliputi yakni Ponorogo, Madiun, Kota Madiun, Ngawi, Magetan, Pacitan, Nganjuk dan Jombang. Pengabdian kepada masyarakat ini merupakan kegiatan tahap 2. Tahap pertama telah dilakukan di daerah bojonegoro dan sekitarnya pada tahun 2020 .

\section{METODE}

Pelaksanaan kegiatan pelatihan dan pembuatan kurva "S" yang lebih detail menggunakan program Microsoft Project bagi guru-guru di SMK di Wilayah Kerja 4 Provinsi Jawa Timur. Kegiatan pelatihan yang akan dilakukan meliputi:

1. Ceramah / penjelasan dengan powerpoint dan Tanya jawab secara daring: (a) didahului dengan Pre test; (b) penyajian materi dengan penjelasan secara umum materi Rencana Anggaran Belanja (RAB) dengan fokus pada perencanaan time schedule dan pembuatan kurva " $S$ "; (c) penggunaan 
program Microsoft Project untuk pembuatan jadwal proyek (time schedule); dan (d) kemudian dibuka termin Tanya jawab.

2. Diskusi dengan menuangkan pokok pikiran berkaitan dengan pembelajaran materi dan praktek Rencana Anggaran Belanja (RAB) menggunakan Microsoft Excel dan perencanaan time schedule menggunakan Microsoft Project.

3. Praktek membuat materi Microsoft Project dipandu oleh Tim PKM

4. Evaluasi hasil dengan diberikan post-test. Indikator yang digunakan pada soal post-test tersebut sebagai berikut :

a. Kemampuan peserta dalam memahami dasar-dasar penjadwalan proyek

b. Kemampuan peserta menerapkan User Interface Microsoft Project

c. Kemampuan peserta menjalankan pengaturan kalender pada Microsoft Project

d. Kemampuan peserta melakukan input data Microsoft Project

e. Kemampuan peserta dalam mengaplikasikan Gant Chart Microsoft Project

f. Kemampuan peserta dalam mengaplikasikan Network Planning Microsoft Project

g. Kemampuan peserta dalam menentukan durasi total proyek

h. Kemampuan peserta dalam menentukan pekerjaan kritis proyek Microsoft Project

i. Kemampuan peserta dalam menentukan pekerjaan nonkritis proyek Microsoft Project

\section{HASIL DAN PEMBAHASAN}

Kegiatan pelatihan Microsoft Project dilaksanakan secara online pada tanggal 1 s.d 6 September 2021. Selain itu juga dilakukan latihan mandiri, pendampingan, dan penugasan yang dilakukan secara online pada tanggal 8 September 2021. Sambutan dari perwakilan sekolah sewilayah kerja 4 Provinsi Jawa Timur diwakili oleh Kepala Sekolah SMKN Kudu Jombang. Tim PKM Unesa juga melibatkan 2 mahasiswa S1 Pendidikan Teknik Bangunan FT Unesa untuk membantu kegiatan pelaksanaan pelatihan.

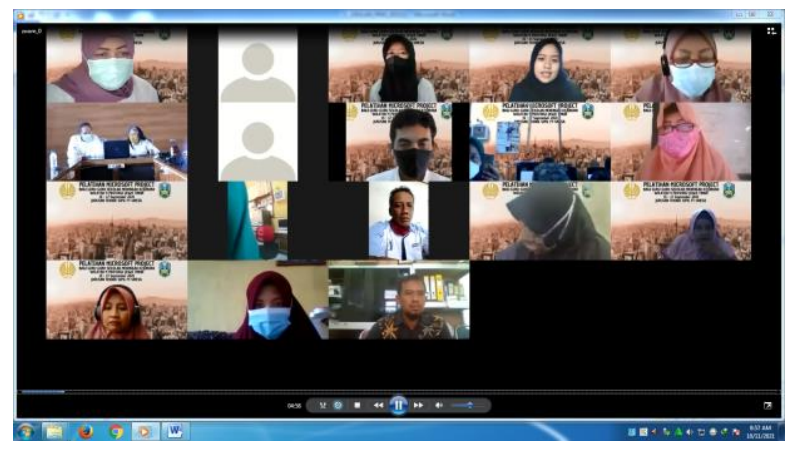

Gambar 1. Registrasi peserta saat kegiatan PKM

Total peserta kegiatan pelatihan Microsoft Project sebanyak 38 guru dari SMK di Wilayah Kerja 4 Propinsi Jawa Timur. Guru-guru tersebut berasal dari SMKN Kudu, SMKN 1 Bendo 
Magetan, SMKN 1 Donorojo, SMKN 1 Madiun, SMKN 1 Geneng, SMKN 2 Ngawi, SMKN 1 Mojokerto, SMKN 3 Jombang, dan SMKN Sawoo Ponorogo.

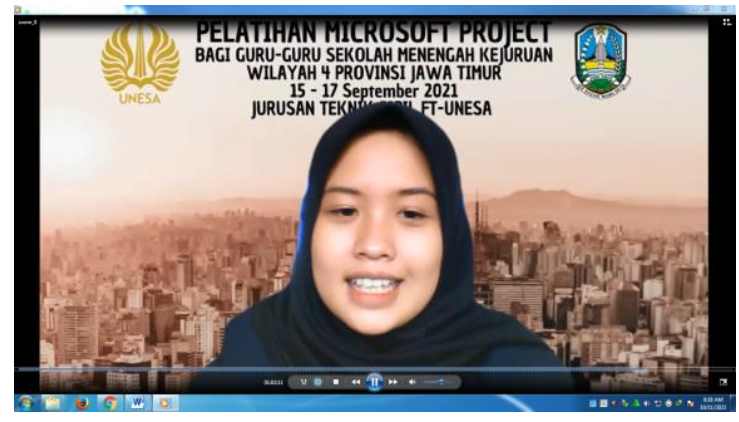

Gambar 2. Perwakilan mahasiswa S1 Pendidikan Teknik Bangunan yang menjadi MC

Peran 2 mahasiswa S1 Pendidikan Teknik Bangunan dalam kegiatan pelatihan Microsoft Project, yaitu :

1. Arvieka Sabilla Putri Setiadi bertugas sebagai : MC, membantu membuat desain sertifikat, memandu pengisian pre-test, post- test, dan evaluasi kegiatan pelatihan

2. Muhammad Sofwan Mu'afi bertugas sebagai sie perlengkapan, memandu dan memberi informasi ke peserta sebelum pelatihan, ketika pelatihan, dan akhir pelatihan menggunakan whatsapp group.

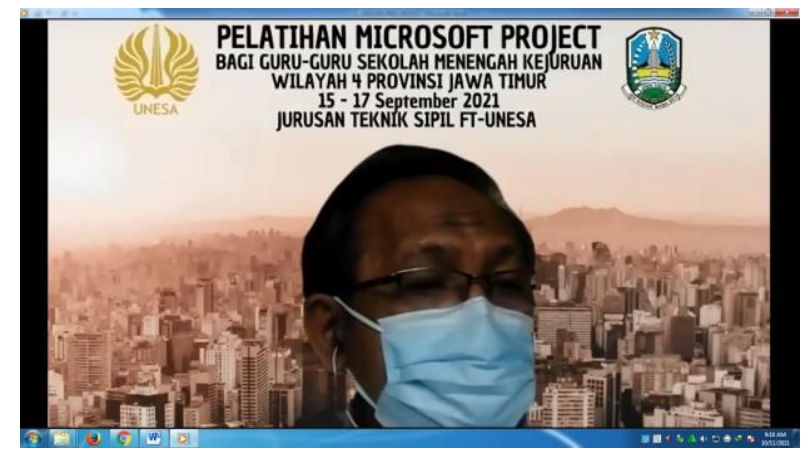

Gambar 3. Sambutan dari perwakilan Tim PKM Unesa

Bapak Hendra Wahyu Cahyaka., S.T., M.T. mewakili tim PKM Jurusan Teknik Sipil FT Unesa dalam sambutan kegiatan Pelatihan Microsoft Project.

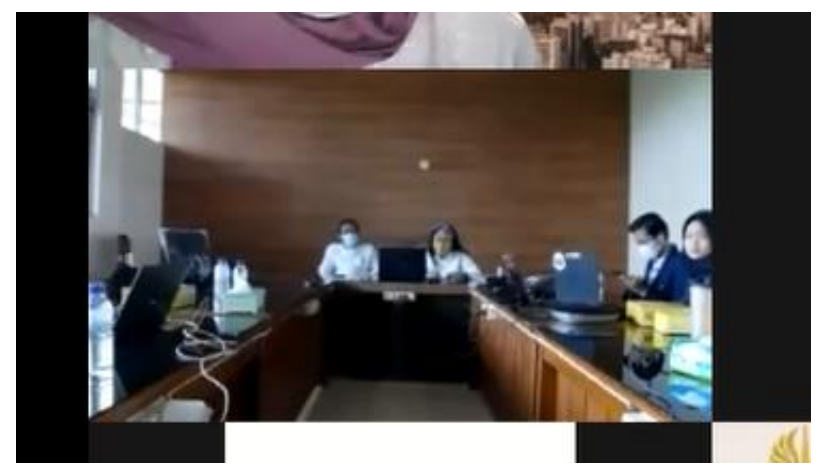

Gambar 4. Tim PKM Unesa dan mahasiswa saat pembukaan kegiatan 
Tim PKM, narasumber, dan mahasiswa dalam satu ruangan di gedung E2 lantai 2 FT Unesa dalam kegiatan pelatihan Microsoft Project. Hal ini dilakukan untuk mempermudah koordinasi selama kegiatan berlangsung, tentunya dengan tetap mematuhi protocol kesehatan yang ketat. Kegiatan pelatihan ini khusus pada kegiatan latihan mandiri dan penugasan tanggal 8 september 2021 .

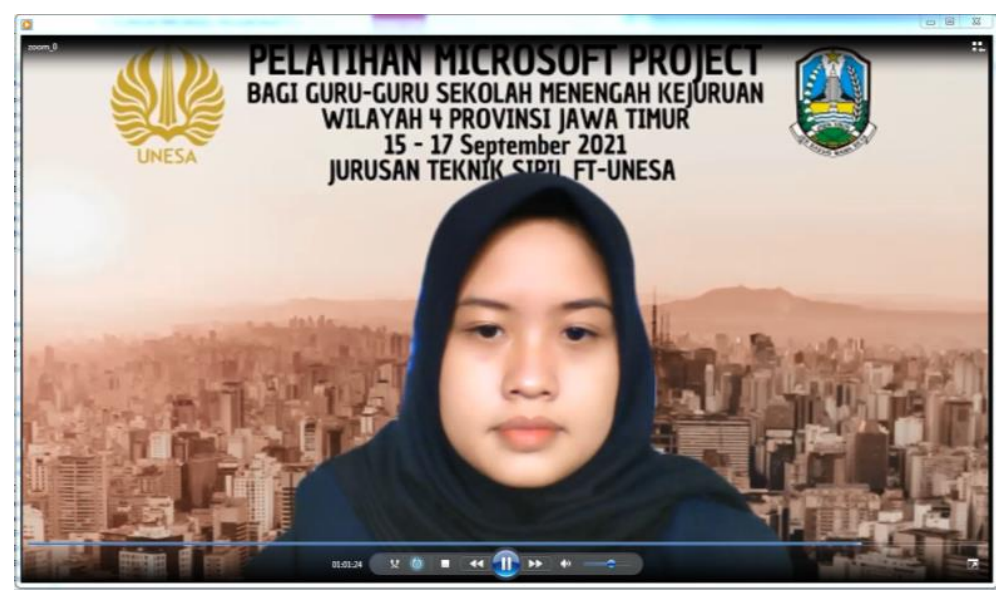

Gambar 5. Pre Tes dilakukan ke peserta sebelum penyampaian materi oleh tim

Sebelum kegiatan pelatihan dimulai maka dilakukan pre-test ke peserta. Kegiatan pre-test ini dilakukan untuk mengukur kemampuan awal peserta sebelum memperoleh materi pelatihan Ms project. Pre-test ini disajikan melalui googleform yang dibagikan ke peserta melalui chat di zoom. Link googleform dapat diakses melalui : https://bit.ly/Pre-Test_PKM_MsProject_JTSFTUnesa_2021.

Materi pelatihan Ms project yang diberikan ke peserta pelatihan, meliputi : (1) Dasar-dasar penjadwalan proyek; (2) User Interface Ms. Project; (3) Setting Kalender Ms. Project; (3) Input Data Ms. Project; (4) Gant Chart Ms. Project; (5) Network Planning Ms. Project; (6) Penentuan Durasi Total Proyek; (6) Pekerjaan Kritis Proyek Ms. Project; (7) Pekerjaan Nonkritis Proyek Ms. Project; dan (8) Latihan Mandiri Ms. Project.

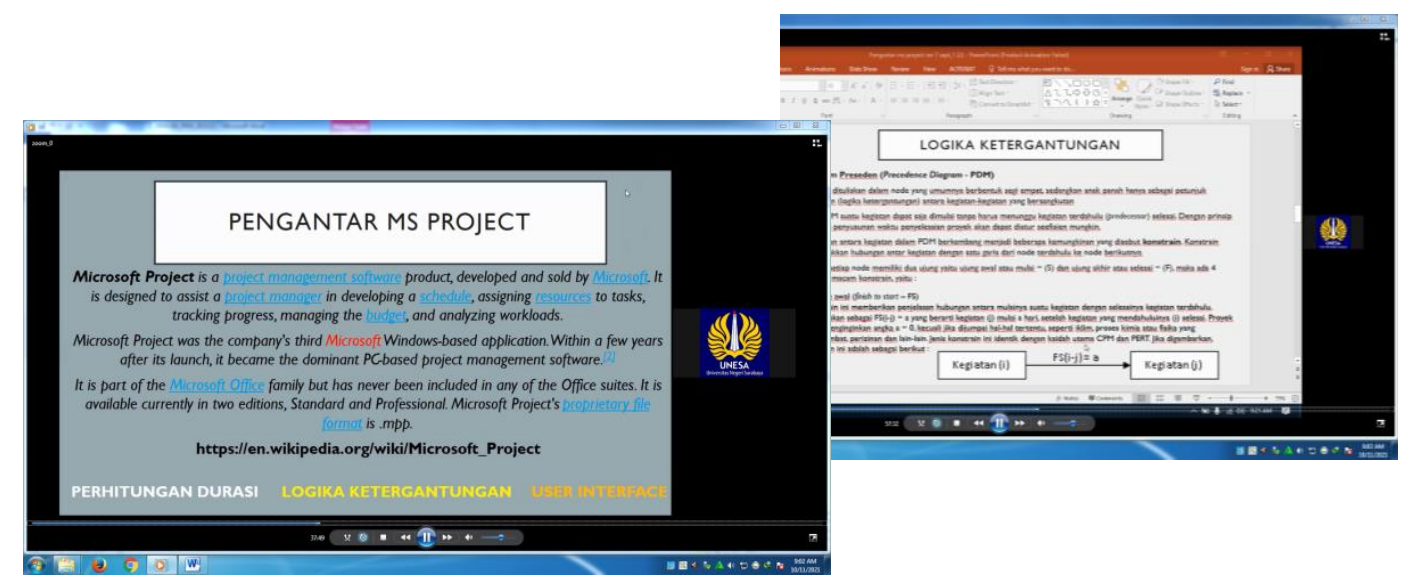

Gambar 6. Pemaparan materi oleh narasumber sesi 1 
Kegiatan pada sesi 1 disampaikan oleh (1) Krisna Dwi Handayani., S.T., M.MT., M.T.; (2) Hendra WC., S.T., M.T.; dan (3) Ir. Mas Suryanto HS., S.T., M.T. Materi yang disampaikan pada sesi ini meliputi materi (1) Dasar-dasar Penjadwalan Proyek (2) User Interface Microsoft Project.
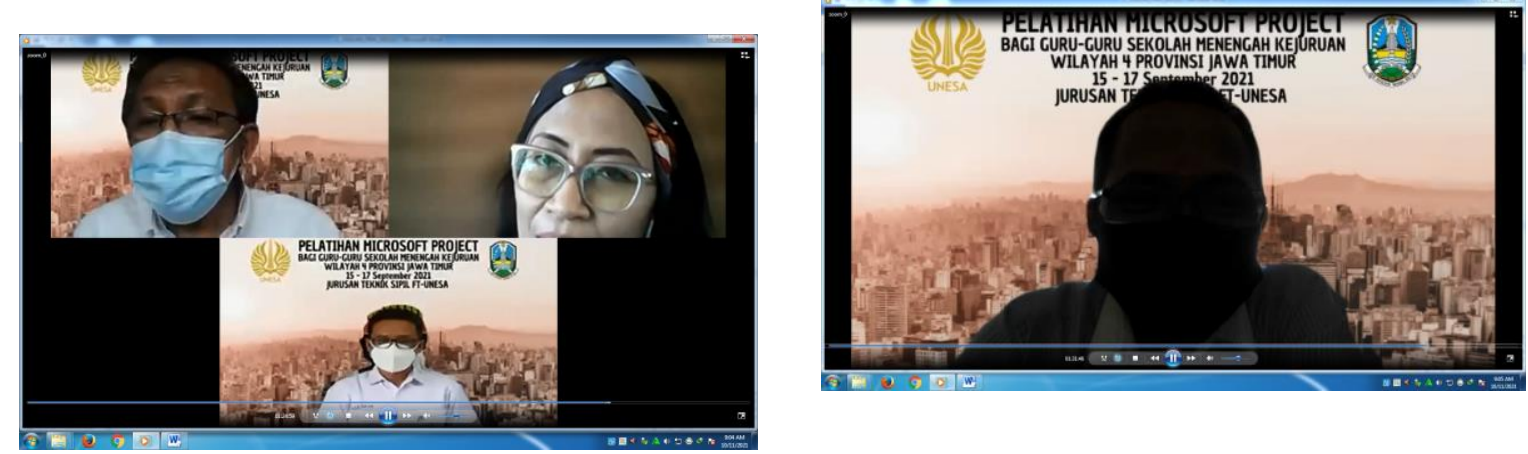

Gambar 7. Tanya jawab oleh Peserta dan narasumber pada kegiatan sesi 1

Antusiasme peserta pada sesi 1 dapat dilihat ketika kegiatan pelaksanaan pelatihan baik ketika narasumber menyampaikan materi maupun saat kegiatan Tanya jawab.
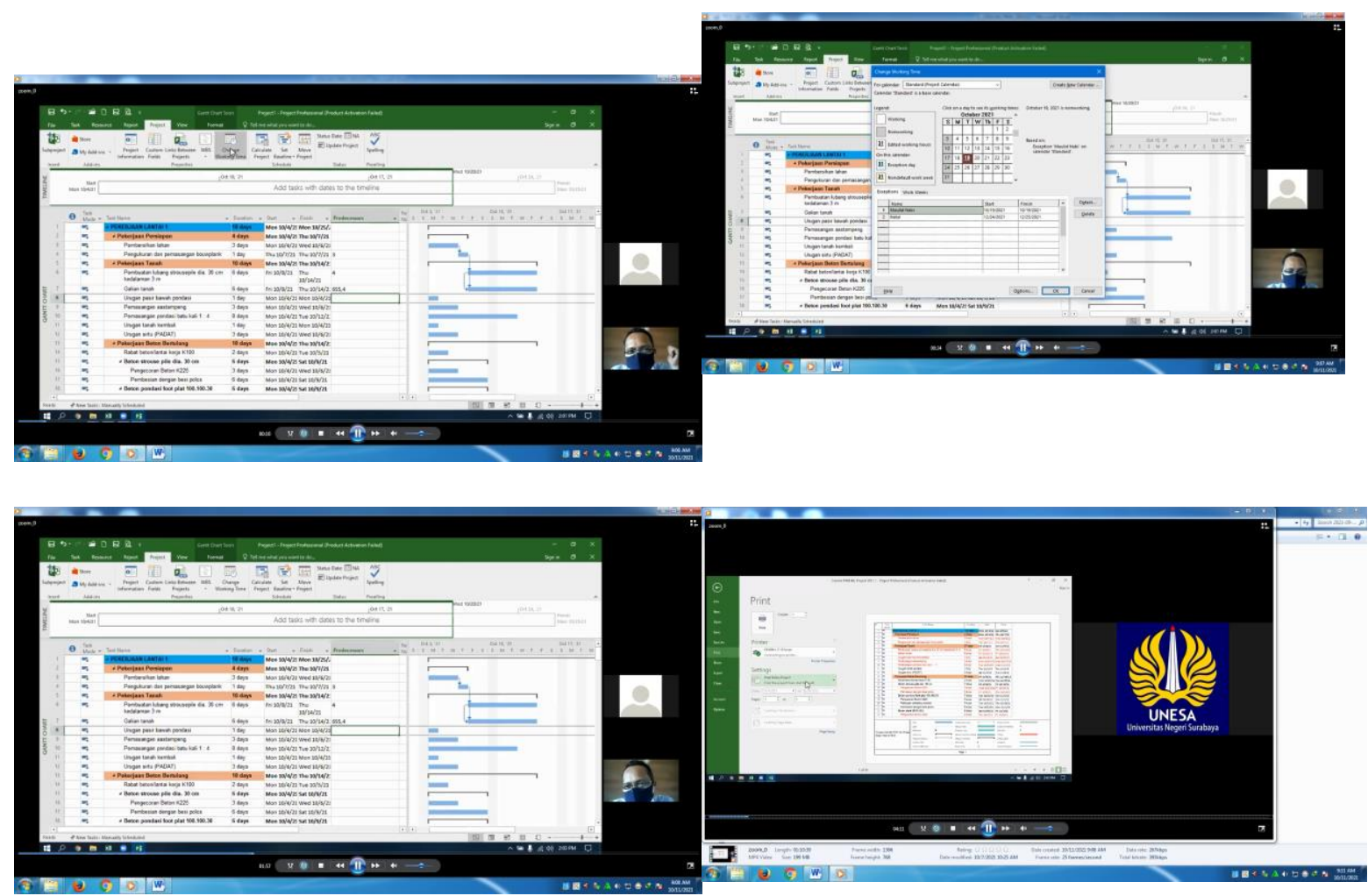

Gambar 8 Pemaparan materi oleh narasumber sesi 2

Kegiatan pada sesi 2 disampaikan oleh (1) Krisna Dwi Handayani., S.T., M.MT., M.T.; (2) Hendra WC., S.T., M.T.; dan (3) Ir. Mas Suryanto HS., S.T., M.T. Materi yang disampaikan pada sesi ini meliputi materi (1) Setting Kalender Microsoft Project; (2) Input Data Microsoft Project; (3) Gant Chart Microsoft Project; (4) Network Planning Microsoft Project; (5) Penentuan Durasi Total 
Proyek; (6) Pekerjaan Kritis Proyek Microsoft Project; dan (7) Pekerjaan Nonkritis Proyek Microsoft Project.
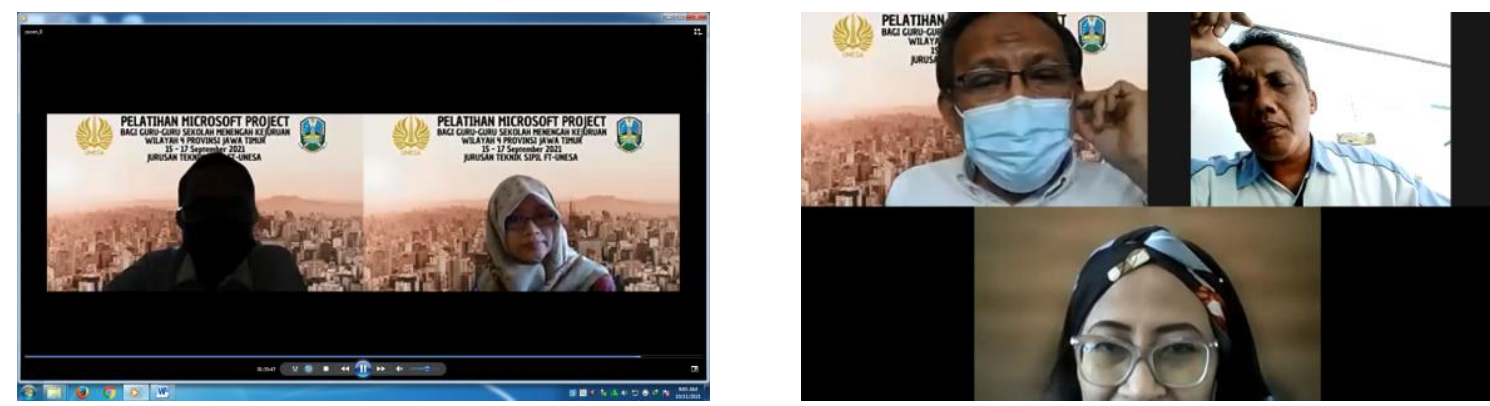

Gambar 9. Tanya jawab oleh Peserta dan narasumber pada kegiatan sesi 2

Peserta pada sesi 2 juga sangat antusias saat mengikuti pelatihan, hal ini dapat dilihat ketika kegiatan pelaksanaan pelatihan baik ketika narasumber menyampaikan materi maupun saat kegiatan Tanya jawab.

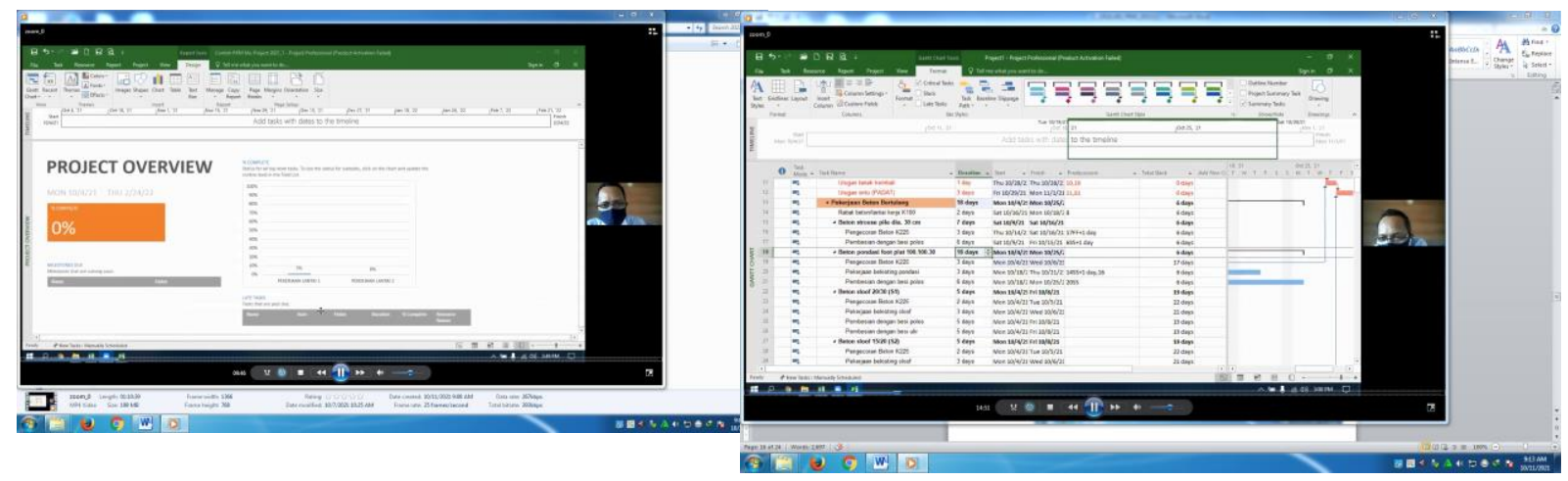

Gambar 10 Pemaparan materi oleh narasumber sesi 3

Kegiatan pada sesi 3 disampaikan oleh (1) Krisna Dwi Handayani., S.T., M.MT., M.T.; (2) Hendra WC., S.T., M.T.; dan (3) Ir. Mas Suryanto HS., S.T., M.T. Pada sesi ini juga merupakan Latihan Mandiri Microsoft Project yang dilakukan oleh peserta didampingi oleh tim PKM Unesa. Peserta langsung melakukan latihan mandiri dengan bersemangat menggunakan laptop masingmasing secara daring. Laptop peserta telah terinstal aplikasi Microsoft Project pada H-1 pelaksanaan pelatihan. Sehingga saat hari pelaksanaan peserta tinggal mengoperasikan dan latihan secara langsung. 


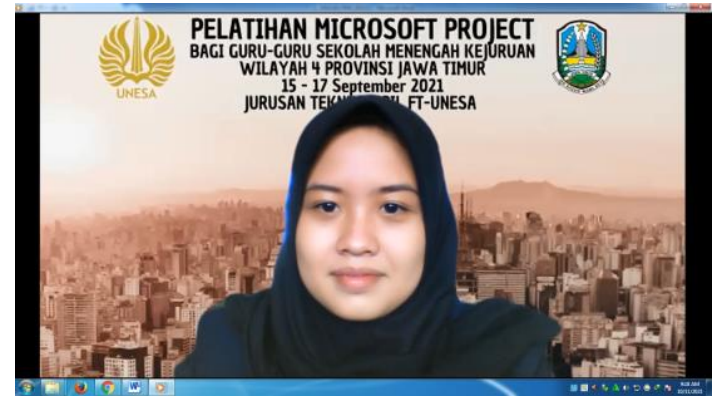

Gambar 11. Pengisian Post-test

Setelah penyampaian materi, tanya jawab, dan latihan mandiri telah dilakukan, maka tahap berikutnya adalah kegiatan post-test. Kegiatan post-test ini dilakukan untuk mengukur kemampuan akhir peserta setelah memperoleh materi pelatihan Microsoft Project. Post-test ini disajikan melalui googleform yang dibagikan ke peserta melalui chat di zoom. Link google form dapat diakses melalui : https://bit.ly/Post-Test_PKM_MsProject_JTSFTUnesa_2021.
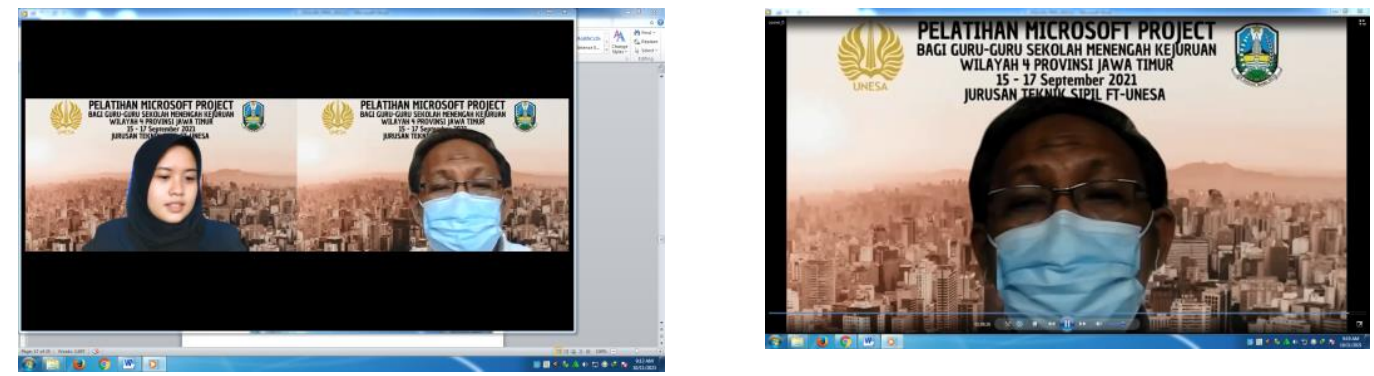

Gambar 12. Penutupan kegiatan PKM

Rangkaian kegiatan PKM pelatihan Microsoft Project telah mulai dari registrasi peserta hingga post-test telah dilaksanakan. Tahap selanjutnya adalah kegiatan penutupan pelatihan. Pada sesi ini dilakukan dokumentasi, penyampaian informasi terkait tugas-tugas yang harus dikumpulkan peserta melalui google classroom.
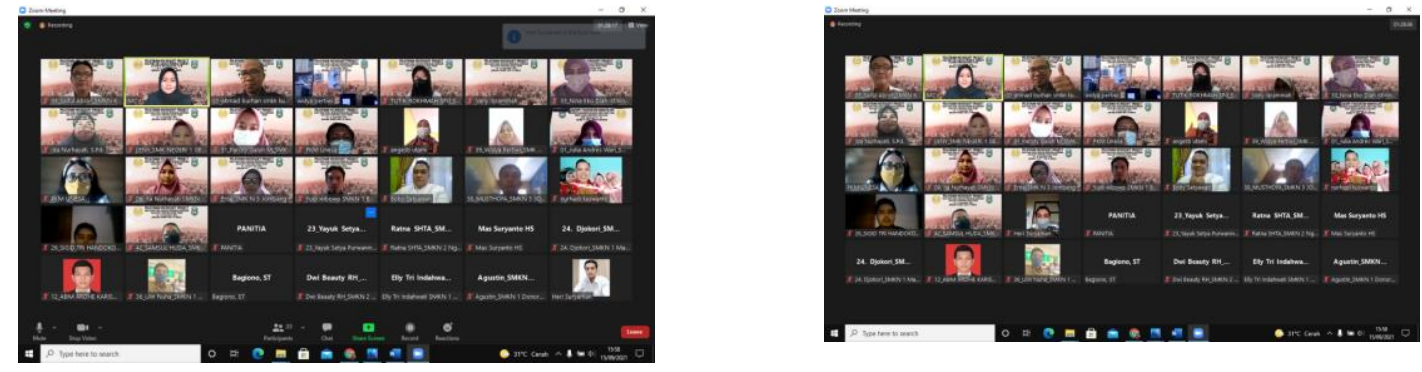

Gambar 13. Foto bersama saat kegiatan penutupan

Penilaian untuk peserta sebagai bahan pertimbangan peserta berhak atau tidaknya memperoleh sertifikat, maka peserta wajib mengikuti seluruh rangkaian kegiatan pelatihan; (2) peserta mengumpulkan tugas hasil dari pelatihan ke dalam google clasroom. 


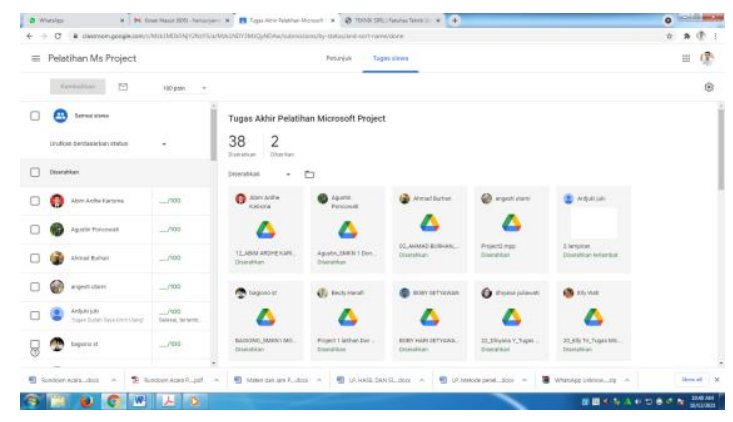

Gambar 14. Tugas peserta yang telah dikumpulkan oleh peserta di googleclasroom

Sebagai alat ukur berhasil atau tidaknya dari pelaksanaan kegiatan PKM Microsoft Project, maka dilakukan evaluasi kegiatan. Evaluasi kegiatan pelatihan diberikan ke peserta melalui chat zoom. Evaluasi kegiatan pelatihan Microsoft Project dapat diakses melalui link googleform berikut ini https://bit.ly/Evaluasi_PKM MsProject JTSFTUnesa 2021.

Tabel 1. Indikator capaian keberhasilan kegiatan pelatihan

\begin{tabular}{clcc}
\hline No & \multicolumn{1}{c}{ Indikator } & Target $(\%)$ & Capaian (\%) \\
\hline 1 & Dasar-dasar penjadwalan proyek & 100 & 85 \\
2 & User Interface Microsoft Project & 100 & 82 \\
3 & Setting Kalender Microsoft Project & 100 & 78 \\
4 & Input Data Microsoft Project & 100 & 87 \\
5 & Gant Chart Microsoft Project & 100 & 90 \\
6 & Network Planning Microsoft Project & 100 & 80 \\
7 & Penentuan Durasi Total Proyek & 100 & 82 \\
8 & Pekerjaan Kritis Proyek Microsoft Project & 100 & 78 \\
9 & Pekerjaan Nonkritis Proyek Microsoft & 100 & 80 \\
& Project & & 85 \\
\hline
\end{tabular}

Ketercapaian keberhasilan dari peserta dalam mengikuti pelatihan berdasarkan dari tabel diatas dapat pada indikator capaian keberhasilan rata-rata sebesar 82\%. Dalam PKM terdahulu peserta mampu menganalisis apa saja yang harus dipersiapkan untuk mengembangkan usaha (Prihatiningsih et al., n.d.). selanjutnya dalam pelatihan pada masyarakat menunjukkan bahwa peserta setelah mengikuti pelatihan pengetahuan dan keterampilannya menjadi semakin baik (Kustiandi et al., 2020).

Upaya yang dilakukan untuk mengatasi kesulitan yang dialami peserta dalam mengaplikasikan Microsoft Project pada beberapa item indikator adalah latihan dengan kelompok untuk mempermudah keberhasilan capaian. Pandangan peserta bahwa pelaksanaan pelatihan telah memberikan manfaat yang mendalam (Eliza et al., 2019).

\section{KESIMPULAN}

Pelatihan Microsoft Project yang dilakukan secara daring ini telah terlaksana dengan hasil sebagai berikut: (1) Pelatihan Microsoft Project secara daring ini sebagai alternative solusi 
pelaksanaan PKM di masa pandemic Covid-19; (2) Capaian keberhasilan setiap peserta pelatihan dari SMK se wilayah kerja 4 Provinsi Jawa Timur sebanyak 38 guru rata-rata sebesar 82\%; (3) Peningkatan kompetensi professional bagi guru dan memberikan sertifikat kompetensi; serta (4) terjalin peningkatan kerja sama SMK se wilayah kerja 4 Provinsi Jawa Timur dan Universitas Negeri Surabaya.

\section{UCAPAN TERIMAKASIH}

Tim PKM Pelatihan Microsoft Project mengucapkan terima kasih kepada semua pihak yang telah mendukung kegiatan sehingga dapat terlaksana dengan baik. Penulis juga mengucapkan terima kasih kepada LPPM dan Fakultas Teknik Universitas Negeri Surabaya yang telah memberi dukungan financial terhadap pengabdian ini. Terima kasih juga kami sampaikan kepada semua pihak dari SMK di wilayah kerja 4 Provinsi Jawa Timur yang telah bersedia bermitra dengan Universitas Negeri Surabaya.

\section{DAFTAR PUSTAKA}

Arief, M., Churiyah, M., Basuki, A., Adi, B., \& Gunawan, A. (2020). Peningkatan Kompetensi Guru SMK Kabupaten Malang Melalui Pelatihan E-Filing. Jurnal Graha Pengabdian, 2(1), 71-77. http://journal2.um.ac.id/index.php/jgp/article/download/12161/5184

Cahyono, K. E., \& Suryawirawan, O. A. (2021). Pelatihan Pengelolaan Persediaan, Pemasaran Dan Pembukuan Sederhana Untuk UMKM Desa Pakis Kecamatan Kunjang Kabupaten Kediri. Jurnal Abadimas Adi Buana, 4(2), 122-126. https://doi.org/10.36456/abadimas.v4.i2.a2685

Eliza, F., Asnil, A., \& Husnaini, I. (2019). Peningkatan Kompetensi Guru SMK Melalui Pelatihan Software Engineering. Jtev (Jurnal Teknik Elektro Dan ..., 5(2), 67-74. http://ejournal.unp.ac.id/index.php/jtev/article/view/106640

Hidayat, W. N., Sutikno, T. A., Dwi, C., Kartikasari, I., \& Firdaus, A. F. (n.d.). PENINGKATAN KETERAMPILAN PEMBUATAN MEDIA PEMBELAJARAN BERBASIS AUGMENTED REALITY visi khusus. Visi yang ingin diwujudkan dari ketiga sekolah ini ialah informasi kepada siswa terkait subjek pelajaran. Hal ini berarti media menjadi.

Kustiandi, J., Jaelani, M. I., Khumairoh, N., \& ... (2020). Peningkatan Kesejahteraan Masyarakat Melalui Pelatihan Diferensiasi Produk Olahan Susu Sapi Desa Ngembal. Jurnal Graha Pengabdian, 2(3), 242-249. http://journal2.um.ac.id/index.php/jgp/article/view/14993

Prihatiningsih, R., Wardani, A., Ningsih, G., Ni, I., \& Anggara, M. K. M. (n.d.). KOPI UNTUK MENINGKATKAN PEREKONOMIAN mengurangi risiko terkena diabetes tipe 2 ( Rahajeng, 2010 ). pengolahan, sehingga tidak mempunyai nilai jual yang tinggi . Menurut Hartini.

Sopandi, T. (2021). Pelatihan Daring Pemanfaatan Jerami Padi Sebagai Media Tumbuh Pada Budidaya Jamur Merang. Jurnal Abadimas Adi Buana, 4(2), 79-90. https://doi.org/10.36456/abadimas.v4.i2.a2689

Wena, M., Suparno, S., \& Pribadi, P. (2019). Pelatihan Penanaman Nilai-Nilai Etika Bisnis Bagi Praktisi Usaha Jasa Konstruksi. Jurnal Graha Pengabdian. http://journal2.um.ac.id/index.php/jgp/article/view/11058 